\title{
STUDI TIMBULAN, KOMPOSISI, DAN POTENSI DAUR ULANG SAMPAH KAWASAN PT SEMEN PADANG
}

\author{
Yommi Dewilda, Yeggi Darnas, Borris Afdhal Anwar \\ Laboratorium Buangan Padat, Jurusan Teknik Lingkungan Universitas Andalas \\ Email: yommi_tl@ft.unand.ac.id
}

\begin{abstract}
ABSTRAK
Tujuan penelitian ini adalah menentukan timbulan, komposisi dan potensi daur ulang sampah PT Semen Padang. Rata-rata timbulan sampah harian PT Semen Padang dalam satuan berat adalah $0,076 \mathrm{~kg} / \mathrm{o} / \mathrm{hr}$ sedangkan timbulan dalam satuan volume adalah $0,954 \mathrm{l} / \mathrm{h}$. Berdasarkan sumber, diperoleh timbulan sampah fasilitas perkantoran 1,688 $\mathrm{l} / \mathrm{h}$, fasilitas sekolah 0,485 $\mathrm{l} / \mathrm{o} / \mathrm{h}$, fasilitas perumahan 0,675 $\mathrm{l} / \mathrm{h}$, fasilitas industri 0,686 $\mathrm{lo} / \mathrm{h}$, fasilitas kesehatan 0,959 $\mathrm{lo} / \mathrm{h}$, fasilitas social center 3,117 $\mathrm{l} / \mathrm{o} / \mathrm{h}$, fasilitas olahraga 1,181 l/o/h, fasilitas ibadah 0,107 l/o/h, jalan $1.067 \mathrm{l} / \mathrm{m} 2 / \mathrm{h}$, dan taman 1,231 $\mathrm{l} / \mathrm{m} 2 / \mathrm{h}$. Komposisi sampah didominasi oleh sampah organik 96,940\%, yang terdiri atas sampah sisa makanan 29,720\%, kertas 29,450\%, plastik 21,350\%, sampah halaman $12,350 \%$, tekstil 3,050\%, kayu 0,580\%, karet 0,420\%, dan sampah anorganik hanya $3,060 \%$ yang terdiri atas logam non ferrous 1,340\%, logam ferrous 1,220\%, kaca 0,480\%, dan sampah lain-lain 0,020\%. Komponen sampah yang bepotensi didaur ulang adalah sampah halaman 100\%, sampah plastik 96,090\%, logam non ferrous 83,590\%, sampah makanan $80,280 \%$, sampah kaca 77,810\%, sampah kertas $71,220 \%$, sampah logam ferrous $66,670 \%$, dan sampah kayu 52,130\%. Rata-rata potensi daur ulang sampah berdasarkan sumber sebesar $83,800 \%$ yang terdiri dari potensi daur ulang sampah kering $36,51 \%$ dan potensi daur ulang sampah basah 47,900\%.
\end{abstract}

Kata kunci: komposisi sampah, potensi daur ulang sampah, PT Semen Padang, timbulan sampah.

\begin{abstract}
The aim of this research are to determine solid waste generation, the composition of solid wate, and solid waste recycling potential in PT Semen Padang area. The average of solid waste generation is 0,954 liter/person/day for a unit volume or 0,076 kg/person/dy for weight unit. Based on the sources, obtained office complexs facilities generations is 1,688 $\mathrm{l} / \mathrm{o} / \mathrm{h}$, schools facilities $0,485 \mathrm{l} / \mathrm{h}$, residents facilities $0,675 \mathrm{l} / \mathrm{o} / \mathrm{h}$, industries facilities $0,686 \mathrm{l} / \mathrm{o} / \mathrm{h}$, healthy facility $0,959 \mathrm{l} / \mathrm{o} / \mathrm{h}$, social center facilities $3,117 \mathrm{l} / \mathrm{o} / \mathrm{h}$, sports facilities $1,181 \mathrm{l} / \mathrm{o} / \mathrm{h}$, regions facilities $0,107 \mathrm{l} / \mathrm{o} / \mathrm{h}$, road $1,067 \mathrm{l} / \mathrm{m} 2 / \mathrm{h}$, and the park $1,231 \mathrm{l} / \mathrm{m} 2 / \mathrm{h}$. Waste composition is dominated by 96,940\% of organic waste, which consist of the food waste $29,720 \%$, paper waste $29,450 \%$, plastic waste $21,350 \%$, yard waste $12,350 \%$, textile waste $3,050 \%$, wood 0,580\%, rubber 0,420\%, and inorganic waste is only 3,060\% which consist of non ferrous metal 1,340\%, ferrous metal 1,220\%, glass 0,480\%, etc $0,020 \%$. Component of the waste potentially recycable is the yard waste at $100 \%$, plastic waste $96,090 \%$, non ferrous metal 83,590\%, which consist of potenial for recycling of dry residues $36,51 \%$ and $47,900 \%$ wet waste recycling potential.
\end{abstract}

Keywords: composition of solid waste, PT Semen Padang, solid waste generation, solid waste recycling potential. 


\section{PENDAHULUAN}

Sampah merupakan semua buangan yang dihasilkan oleh aktivitas manusia dan hewan yang berbentk padat, lumpu, cair maupun gas yang dibuang karena tidak dibutuhkan atau tidak diinginkan lagi (Damanhuri, 2004). Penentuan timbulan, komposisi dan potensi daur ulang sampah sangat penting dalam perencanaan dan evaluasi sistem manajemen persampahan. Timbulan sampah merupakan volume sampah atau berat sampah yang dihasilkan dari jenis sumber sampah (perumahan, komersil, perkantoran konstruksi dan pembongkaran, industri dan pertanian) di wilayah tertentu per satuan waktu (DPU, 1999).

Timbulan sampah sangat diperlukan untuk menentukan dan mendesain peralatan yang digunakan dalam transportasi sampah, fasilitas recovery material, dan fasilitas Tempat Pembuangan Akhir (TPA) sampah.

$\begin{array}{lcr}\text { Komposisi } & \text { sampah } & \text { merupakan } \\ \text { penggambaran } & \text { dari } & \text { masing-masing }\end{array}$ komponen yang terdapat pada buangan padat dan distribusinya, biasanya dinyatakan dalam persentase berat (\% berat). Komposisi sampah dikelompokkan atas sampah organik (sisa makanan, kertas, plastik, kain (tekstil), karet, sampah halaman, kayu, dan lain-lain) dan sampah anorganik (kaca, kaleng, logam, dan lainlain (Veronika, 2008). Penelitian tentang timbulan, komposisi dan potensi daur ulang belum pernah dilakukan di PT Semen Padang, sehingga perlu dilakukan penelitian tersebut di PT Semen Padang.

\section{METODOLOGI PENELITIAN}

Tahapan penelitian terdiri atas:

1. Studi Literatur
Mencakup teori dasar yang berhubungan dengan timbulan dan komposisi sampah yang diperoleh dari buku referensi, jurnal dan penelitian sebelumnya.

2. Pengumpulan Data

Pengumpulan data terdiri dari pengumpulan data sekunder dan pengumpulan data primer. Data sekunder yang perlu dalam penelitian ini, meliputi:

a. Gambaran umum kawasan PT

SemenPadang yang meliputi luas, batasan wilayah, dan tata guna lahan kawasan PT semen Padang.

b. Sistem pengelolaan persampahan yang telah dilaksanakan oleh pihak yang berwenang di kawasan PT Semen Padang.

c. Jumlah pegawai PT Semen Padang.

d. Jumlah fasilitas yang terdapat di PT Semen Padang, seperti: kawasan pabrik, area perumahan, dan fasilitas umum lainya

e. Luas masing-masing fasilitas yang ada di PT Semen Padang.

f. Peta-peta kawasan PT Semen Padang, seperti peta tata guna lahan dan peta administrasi.

Pengambilan data primer melalui langkah-langkah berikut ini:

a. Survei pendahuluan

Kegiatan yang dilakukan berupa peninjauan langsung ke lokasi masing-masing sumber sehingga hambatan-hambatan yang mungkin akan ditemui selama penelitian dapat diminimalkan.

b. Persiapan peralatan dan perlengkapan penelitian

Peralatan dan perlengkapan yang digunakan pada penelitian ini antara lain: 
- Alat pengambil sampel berupa kantong plastik hitam dengan volume 40 liter;

- Timbangan (0-5) kg, (0-10) kg dan neraca analitik;

- Perlengkapan berupa sarung tangan, masker dan terpal.

c. Sampling

Sampling dilakukan 8 hari berturut-turut pada lokasi yang sama. Untuk waktu pengambilan sampel kawasan perumahan dilakukan selama 24 jam, sedangkan pengambilan sampel untuk kawasan fasilitas lainya dilakukan selama jam kerja.

3. Pengolahan dan Analisis Data

1. Perhitungan timbulan

Timbulan sampah dapat dinyatakan dalam satuan berat (kg/orang/hari, $\mathrm{kg} / \mathrm{m}^{2} /$ hari) dan satuan volume (liter/orang/hari,liter/ $\mathrm{m}^{2} /$ hari).

Timbulan rata-rata didapat dari

$\mathrm{t}$ industri $=\frac{\mathrm{t} 1+\mathrm{t} 2+\mathrm{t} 3+\ldots+\mathrm{t} 15}{\mathrm{n}}$

dimana: $\mathrm{t}=$ Timbulan Sampah

$(1 / \mathrm{hr})$

$$
\begin{gathered}
\mathrm{n}=\text { Jumlah Sumber } \\
\text { Sampling }
\end{gathered}
$$

Dalam perhitungan timbulan sampah diperhitungkan juga faktor koreksi. Fakor koreksi digunakan untuk mengoreksi hasil perhitungan yang telah kita dapat dan juga untuk mendapatkan timbulan sampah per hari. Sehingga dihasilkan perhitungan yang lebih representatif. Sampling yang dilakukan 8 hari berturut-turut mendapatkan dua data untuk dua hari yang sama. Rata-rata dari sampling hari yang sama dijadikan faktor koreksi setelah dibagi dengan data sampling hari pertama, dan untuk mendapatkan data sebenarnya faktor koreksi dikalikan dengan data sampling hari lainnya.

2. Perhitungan komposisi sampah

Untuk menentukan komposisi sampah, dilakukan pemisahan sampah berdasarkan komponenkomponennya, yaitu sampah organik berupa sampah makanan, kertas, plastik, karet, tekstil, dan kayu/sampah halaman serta sampah anorganik berupa logam, kaca/gelas dan lain-lain (styrofoam, baterai). Persen komposisi adalah berat masing-masing komponen sampah dibagi dengan berat total sampah keseluruhan.

3. Perhitungan potensi daur ulang sampah

Perhitungan potensi daur ulang perkomponen, dibedakan atas jenis/komponen sampah yang berpotensi untuk di daur ulang seperti kertas, plastik, kaca, sampah halaman, sampah makanan, kayu, kaleng dan logam. Masing-masing komponen sampah tersebut ditentukan dengan persamaan sebagai berikut:

Potensi daur ulang sampah per komponen

$=\frac{\text { berat } \text { komponen dapat didaur ulang }}{\times 100 \%}$ berat total sampah

Potensi daur ulang sampah per sumber $=\frac{\text { berat } \text { komponen dapat didaur ulang }}{\text { berat total sampah dari sumber }} \times 100 \%$

Perhitungan potensi daur ulang per sumber, dibedakan atas sampah basah dan sampah kering.

\section{Penentuan Jumlah Sampel}

Jumlah sampel dihitung berdasarkan SNI 19-3964-1994, untuk fasilitas perkantoran, sekolah dan perumahan, sedangkan 
jumlah sampel yang tidak dijelaskan dalam SNI 19-3964-1994 maka sampel yang diambil adalah $10 \%$ dari jumlah total fasilitas yang ada, sekurang-kurangnya satu.

Tabel 1. Jumlah Sampel Sampah PT Semen Padang

\begin{tabular}{|c|c|c|c|c|c|}
\hline Fasilitas & $\begin{array}{l}\text { Jumlah } \\
\text { Total }\end{array}$ & $\begin{array}{l}\text { Jumlah } \\
\text { Sampel }\end{array}$ & $\begin{array}{l}\text { Sampling } \\
\text { Ra } \\
\text { tio }\end{array}$ & PSE & $\begin{array}{l}\text { Keandalan } \\
\text { Survei } \\
\text { dalam \% }\end{array}$ \\
\hline Fasilitas Perkantoran & 7 & 3 & \multirow{11}{*}{0,099} & \multirow{11}{*}{0,24} & \multirow{11}{*}{99,86} \\
\hline Fasilitas Olahraga & 3 & 1 & & & \\
\hline Fasilitas Ibadah & 1 & 1 & & & \\
\hline Kegiatan Industri & 3 & 1 & & & \\
\hline Social Center & 11 & 2 & & & \\
\hline Kawasan Sekolah & 6 & 3 & & & \\
\hline Perumahan Pegawai & 170 & 6 & & & \\
\hline Rumah Sakit & 1 & 1 & & & \\
\hline Jalan & - & 1 & & & \\
\hline Taman/Halaman & - & 1 & & & \\
\hline TOTAL & 203 & 20 & & & \\
\hline
\end{tabular}

\section{HASIL DAN PEMBAHASAN}

\section{Timbulan Sampah Kawasan PT Semen Padang}

Timbulan sampah harian terbesar adalah pada hari rabu dan kamis yaitu 1,272 1/o/hr dan 1,289 liter.orang/hari, karena dua hari ini merupakan hari paling sibuk Seperti yang terlihat pada Gambar 1

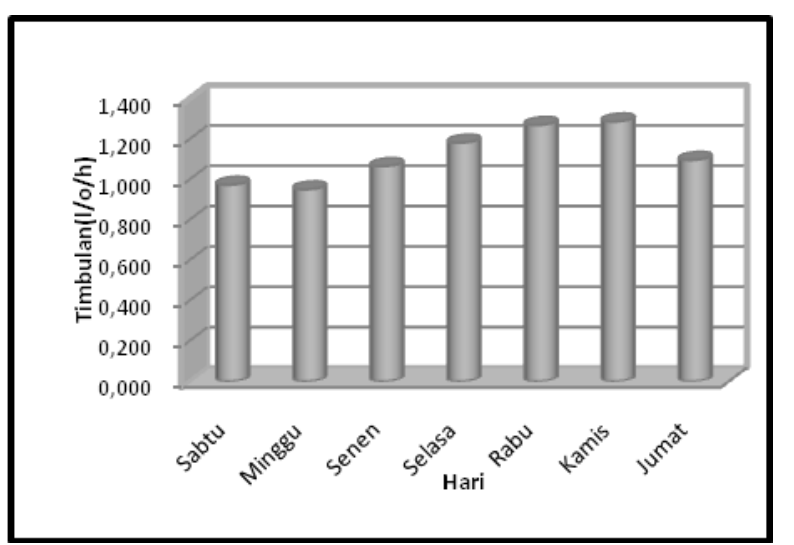

Gambar 1. Rekapitulasi Timbulan Sampah Harian Berdasarkan Fasilitas Kawasan PT Semen Padang
Tabel 2. Rekapitulasi Timbulan Sampah Harian Berdasarkan Fasilitas Dalam Satuan Volume dan Berat

\begin{tabular}{|c|c|c|c|c|c|}
\hline \multirow[t]{2}{*}{ No. } & \multirow[t]{2}{*}{ Lokasi } & \multicolumn{2}{|c|}{$\begin{array}{c}\text { Timbulan } \\
\text { Dalam Satuan } \\
\text { Berat }\end{array}$} & \multicolumn{2}{|c|}{$\begin{array}{c}\text { Timbulan } \\
\text { Dalam Satuan } \\
\text { Volume }\end{array}$} \\
\hline & & $\mathrm{kg} / \mathrm{m}^{2} / \mathrm{h}$ & $\mathrm{kg} / \mathrm{o} / \mathrm{h}$ & $1 / \mathbf{m}^{2} / \mathbf{h}$ & l/o/h \\
\hline 1 & Fasilitas Perkantoran & 0,005 & 0,077 & 0,119 & 1,688 \\
\hline 2 & Fasilitas Sekolah & 0,001 & 0,010 & 0,064 & 0,485 \\
\hline 3 & Fasilitas Perumahan & 0,024 & 0,344 & 0,047 & 0,675 \\
\hline 4 & Fasilitas Industri & 0,001 & 0,036 & 0,018 & 0,686 \\
\hline 5 & Fasilitas Kesehatan & 0,001 & 0,018 & 0,065 & 0,959 \\
\hline 6 & Social Center & 0,015 & 0,087 & 0,521 & 3,117 \\
\hline 7 & Fasilitas olahraga & 0,006 & 0,100 & 0,072 & 1,181 \\
\hline 8 & Fasilitas Ibadah & 0,000 & 0,007 & 0,006 & 0,107 \\
\hline 9 & Jalan & 0,111 & 0,002 & 1,067 & 0,022 \\
\hline 10 & Taman & 0,147 & 0,078 & 1,231 & 0,62 \\
\hline \multicolumn{2}{|r|}{$\begin{array}{l}\text { Rata-rata Timbulan } \\
\text { Sampah per Hari }\end{array}$} & $\mathbf{0 , 0 3 1}$ & 0,076 & 0,321 & 0,954 \\
\hline
\end{tabular}

Dari rekapitulasi ini didapatkan bahwa rata-rata timbulan harian dalam satuan berat adalah $0,031 \mathrm{~kg} / \mathrm{m} 2 / \mathrm{hr}$ atau 0,076 $\mathrm{kg} / \mathrm{o} / \mathrm{hr}$ sedangkan timbulan dalam satuan volume adalah $0,321 \mathrm{l} / \mathrm{m} 2 /$ hari atau 0,954 1/o/hr.

\section{Komposisi Sampah}

Tabel 2 dan Gambar 1 memperlihatkan rekapitulasi komposisi sampah harian. Dari Gambar 2 terlihat komposisi sampah harian terbesar adalah sampah organik yaitu 93,1 - 98,71 \% dengan sampah makanan, sampah kertas, dan plastik mempunyai komposisi terbesar dengan rentangnya berturut-turut $27,48-39,81 \%$, $17,46-35,41 \%, 18,31-24,95 \%$, sedangkan komposis sampah anorganik 0,7 $-6,9 \%$. 
Tabel 3. Rekapitulasi Komposisi Sampah

\begin{tabular}{|l|c|}
\multicolumn{2}{|c|}{ Harian } \\
\hline Komponen Sampah & Komposisi rata ${ }^{2}$ sampah \\
\hline Sampah Organik & 29,72 \\
\hline Sampah Makanan & 29,45 \\
\hline Kertas & 21,35 \\
\hline Plastik & 3,05 \\
\hline Tekstil & 0,42 \\
\hline Karet & 12,35 \\
\hline Sampah Halaman & 3,06 \\
\hline Kayu & 1,22 \\
\hline Total Organik & 0,58 \\
\hline Kaca & 96,94 \\
\hline Logam Ferrous & \\
\hline Total Anorganik & \\
\hline Lain-lain & \\
\hline Total & \\
\hline
\end{tabular}

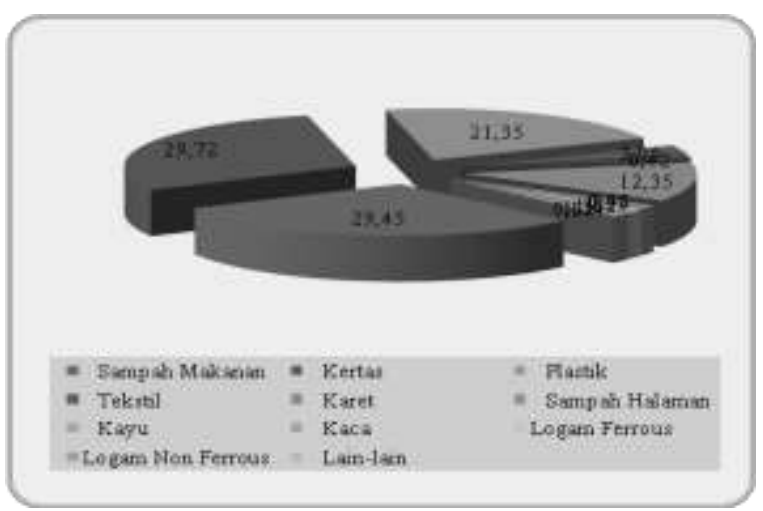

Gambar 2. Komposisi Sampah PT Semen Padang

\section{Potensi Daur Ulang Sampah}

\section{Potensi Daur Ulang Berdasarkan Komponen Sampah}

Komponen sampah yang berpotensi untuk didaur ulang dari sumber Kawasan PT Semen Padang adalah sampah kertas, plastik, kaca, kaleng, logam, kayu, sampah halaman dan sampah makanan.

\section{Sampah Kertas}

Dari hasil penelitian ini, didapatkan ratarata potensi daur ulang sampah kertas fasilitas Kawasan PT Semen Padang adalah sebesar $71,22 \%$; adapun potensi daur ulang terbesar adalah jenis kertas kualitas tinggi 24,20\%; karton 20,57\%; kardus $11,9 \%$; kertas koran $8,21 \%$; dan kertas campuran $6,35 \%$. Kertas yang tidak berpotensi untuk di daur ulang adalah sebesar 28,78\% ; yang terdiri dari kertas tissue yaitu $12,46 \%$ dan pembungkus makanan $11,32 \%$.

Dari hasil penelitian ini, didapatkan potensi daur ulang sampah kertas terbesar berasal dari fasilitas industri $86,17 \%$; lalu disusul oleh fasilitas sekolah 77,55\%; fasilitas olahraga 74,21\%; fasilitas perkantoran 67,04\%; fasilitas kesehatan $66,88 \%$; fasilitas ibadah $61,56 \%$; fasilitas perumahan $57,80 \%$; dan social center $53,90 \%$. Besarnya potensi daur ulang sampah kertas dari fasilitas sekolah dikarenakan fasilitas ini paling banyak menghasilkan sampah kualitas tinggi dan kertas campuran. Social center memiliki potensi daur ulang kertas terkecil, hal ini dikarenakan social center banyak menghasilkan sampah pembungkus makanan dan tissue.

Hasil analisis potensi daur ulang sampah kertas per fasilitas menunjukkan bahwa jenis kertas yang paling berpotensi didaur ulang untuk masing-masing fasilitas kawasan PT Semen Padang adalah kertas kualitas tinggi berupa kertas tulis, kertas HVS yaitu kertas bekas cetak komputer serta kertas bekas struk belanja dan kertas kwitansi, karton, kertas campuran.

\section{Sampah Plastik}

Potensi daur ulang rata-rata sampah plastik fasilitas Kawasan PT Semen Padang adalah sebesar 96,09\%; yang terdiri dari 
jenis plastik LDPE 53,37\%; PETE 27,2 $\%$; HDPE 11,43\%; PP 2,16 \%; dan PVC $1,84 \%$. Sampah plastik yang tidak berpotensi untuk di daur ulang adalah sebesar 3,91\%; yang terdiri dari plastik PS 3,42\%; dan jenis plastik lain sebesar 0,49 $\%$. Potensi daur ulang sampah plastik terbesar berasal dari sampah jalan dan taman sebesar 100\%; dan yang terkecil berasal dari sampah fasilitas olahraga sebesar $85,09 \%$.

Hasil analisis potensi daur ulang sampah plastik per sarana menunjukkan bahwa jenis plastik LDPE (4) merupakan jenis plastik yang paling besar berpotensi untuk didaur ulang untuk sampah fasilitas jalan, taman, fasilitas perkantoran, fasilitas social center, fasilitas industri, fasilitas sekolah, fasilitas perumahan, fasilitas olahraga, dan fasilitas ibadah. LDPE ditemukan dalam bentuk kantong plastik kresek dan tali plastik.

\section{Sampah Kaca}

Potensi daur ulang sampah kaca fasilitas Kawasan PT Semen Padang adalah sebesar 77,08\%; yang terdiri dari jenis kaca warna bening $75,73 \%$ dan kaca warna coklat $1,35 \%$. Kaca yang tidak berpotensi untuk di daur ulang adalah sebesar 22,92\%; yang terdiri dari bola lampu.

\section{Sampah Logam Non Ferrous}

Potensi daur ulang sampah logam non ferros fasilitas Kawasan PT Semen Padang berupa kaleng aluminium sebesar 83,59\%. Potensi daur ulang sampah kaleng terbesar dihasilkan oleh fasilitas Industri $100 \%$ dan yang terkecil berasal dari fasilitas sekolah $70,41 \%$. Jenis sampah kaleng yang berpotensi didaur ulang adalah sampah kaleng aluminium yang bersih/tidak tercampur kontaminan seperti lem dan cat.

\section{Sampah Logam Ferrous}

Potensi daur ulang sampah logam ferros fasilitas Kawasan PT Semen Padang adalah 66,67 \% berupa besi yang tidak tercampur. Potensi daur ulang sampah kaleng terbesar dihasilkan oleh fasilitas Industri, fasilitas perumahan sebesar 100 $\%$, untuk yang tidak berpotensi didaur ulang sebesar $33,67 \%$ berupa besi tercampur yang berasal dari fasilitas sekolah, sedangkan fasilitas lain tidak ditemukan logam ferrous .

\section{Sampah Kayu}

Potensi daur ulang sampah kayu fasilitas Kawasan PT Semen Padanga dalah sebesar $52,13 \%$ berupa kayu bersih (tidak tercmpur kontaminan seperti cat dan asbestos). Sedangkan untuk kayu yang tidak berpotensi untuk di daur ulang adalah sebesar 47,88 \% yaitu berupa kayu tercampur kontaminan.

\section{Sampah Halaman}

Potensi daur ulang sampah halaman fasilitas Kawasan PT Semen Padang adalah sebesar 100\%. Jenis sampah halaman yang dihasilkan sumber adalah daun dan ranting pohon yang berpotensi untuk didaur ulang.

\section{Sampah Makanan}

Potensi daur ulang sampah makanan fasilitas Kawasan PT Semen Padang adalah sebesar 80,28\%, dan yang tidak berpotensi untuk di daur ulang adalah sebesar 19,78 \%. Potensi daur ulang sampah makanan terbesar berasal dari sampah fasilitas Social Center (89,24\%) dan yang terkecil dari fasilitas perumahan $(59,74 \%)$.

Jenis sampah makanan yang berpotensi untuk didaur ulang berupa sampah makanan yang layak kompos berupa sisa makanan, sampah sayuran, sampah buah- 
buahan dan bahan-bahan organik yang mudah terurai lainnya.

\section{Potensi Daur Ulang Berdasarkan Sumber Sampah}

Setelah pengelompokan sampah yang berpotensi didaur ulang dari masingmasing komponen sampah, lalu dilakukan pengelompokan sampah berdasarkan sumber sampah dengan membedakan antara sampah basah dan sampah kering. Sampah basah meliputi sampah halaman, sampah makanan dan kayu. Sampah kering meliputi sampah kertas, plastik, kaca, logam (besi dan baja), kaleng, karet, tekstil dan sampah lain-lain.

Potensi daur ulang sampah kawasan PT Semen Padang sebesar 82,67 \% yang terdiri dari potensi daur ulang sampah basah 42,81\% meliputi $21,29 \%$ sampah halaman; 21,18 \% sampah makanan dan $0,33 \%$ kayu dan potensi daur ulang sampah kering sebesar 39,86\% meliputi 19,46\% kertas; $18,43 \%$ plastik; 0,26\% kaca; 0,8 \% logam ferrous; 0,9 \% logam non ferrous

Potensi daur ulang sampah kawasan PT Semen Padang terbesar berasal dari jalan dan taman yaitu $100 \%$. Potensi daur ulang sampah jalan untuk sampah basah 99,73\% dan untuk sampah kering 0,27\%. Potensi daur ulang sampah taman untuk sampah basah 99,19 \% dan untuk sampah kering $0,81 \%$. Potensi daur ulang untuk sampah kering terbesar berasal dari sekolah yaitu $66,36 \%$ dan sampah basah hanya $20,01 \%$, hal ini disebabkan karena pada sumber tersebut banyak ditemukan sampahsampah seperti plastik, kertas, kaca dan logam. Sedangkan potensi daur ulang sampah terkecil berasal dari perumahan sebesar $53,8 \%$, karena pada pada fasilitas perumahan dihasilkan sampah basah terbesar yang tidak berpotensi untuk didaur ulang sebesar 23,17\%.

\section{Kajian Awal Penerapan Daur Ulang}

Hasil penelitian potensi daur ulang sampah Kawasan PT Semen Padang didapatkan potensi daur ulang sampah basah lebih besar dari pada sampah kering. Dengan melihat besarnya potensi daur ulang, nilai ekonomis, teknologi dan komposisi sampah dapat disimpulkan bahwa penerapan daur ulang di Kawasan PT Semen Padang baru bisa diprioritaskan untuk sampah basah berupa sampah makanan dan sampah halaman serta sampah kering berupa plastik, kertas, kaca, kaleng dan logam. Pengolahan sampah untuk sampah basah adalah pengomposan sedangkan sampah kering berupa daur ulang.

\section{SIMPULAN}

Rata-rata timbulan sampah $0,954 \mathrm{l} / \mathrm{o} / \mathrm{h}$ untuk satuan volume atau $0,076 \mathrm{~kg} / \mathrm{o} / \mathrm{h}$ untuk satuan berat. Berdasarkan sumber, diperoleh timbulan sampah Fasilitas Perkantoran 1,688 1/o/h, Fasilitas Sekolah 0,485 l/o/h, Fasilitas Perumahan 0,675 $\mathrm{l} / \mathrm{o} / \mathrm{h}$, Fasilitas Industri $0,686 \mathrm{l} / \mathrm{o} / \mathrm{h}$, Fasilitas Kesehatan 0,959 1/o/h, Fasilitas Social Center 3,117 1/o/h, Fasilitas Olahraga 1,181 l/o/h, Fasilitas Ibadah 0,107 l/o/h, Jalan 0,1067 l/o/h, dan Taman $1,231 \mathrm{l} / \mathrm{o} / \mathrm{h}$.

Komposisi sampah didominasi oleh sampah organik $96,940 \%$, yang terdiri atas sampah sisa makanan 29,720\%, kertas $29,450 \%$, plastik 21,350\%, sampah halaman 12,350\%, tekstil $3,050 \%$, kayu $0,580 \%$, karet $0,420 \%$, dan sampah anorganik hanya 3,060\% yang terdiri atas logam non ferrous $1,340 \%$, logam ferrous $1,220 \%$, kaca $0,480 \%$, dan sampah lain-lain 0,020\%. 
Komponen sampah yang bepotensi didaur ulang adalah sampah halaman 100\%, sampah plastik 96,090\%, logam non ferrous 83,590\%, sampah makanan $80,280 \%$, sampah kaca 77,810\%, sampah kertas 71,220\%, sampah logam ferrous 66,670\%, dan sampah kayu 52,130\%. Rata-rata potensi daur ulang sampah berdasarkan sumber sebesar 83,800\%, yang terdiri dari potensi daur ulang sampah kering 36,51\% dan potensi daur ulang sampah basah 47,900\% .

\section{DAFTAR PUSTAKA}

Damanhuri, Enri dan Tri Padmi. 2004. Diktat Pengelolaan Sampah, Penerbit TL ITB, Bandung.

Departemen Pekerjaan Umum 1999. Sampah Sebagai Sumber Daya. Jakarta.

Departemen Pekerjaan Umum. 1999 Kajian Pengelolaan Kertas: Jakarta.

Departemen Pekerjaan Umum. 1999. Kajian Pengelolaan Plastik: Jakarta.
Lailany, Widia. 2005. Satuan Timbulan, Komposisi, dan Karakteristik Sampah Domestik Kota Padang. Tugas Akhir Jurusan Teknik Lingkungan. Universitas Andalas. Padang.

Putri, Erisa Viony. 2009. Satuan Timbulan dan Komposisi Sampah Pelayanan Kota Padang. Tugas Akhir Jurusan Teknik Lingkungan Universitas Andalas. Padang.

SNI 19-3964-1994. Metode Pengambilan dan Pengukuran Contoh Timbulan dan Komposisi Sampah Perkotaan.

SNI 19-2454- 2002. Tata Cara Teknik Operasional Sampah Perkotaan.

Tchnobanoglous, 1993. Integrated Solid Waste Management. Mc Graw Hill Inc: New York.

Veronika. 2008. Studi Timbulan, dan Komposisi Sampah Industri Kota Padang. Tugas Akhir Jurusan Teknik Lingkungan Universitas andalas. Padang. 